\title{
L. Obert, O. Laffenetre, F. Sailhan, A. Courvoisier (eds): Groupe de travail et d'etude sur les BMP en orthopedie (GBETO)
}

\section{Bone Morphogenetic Protein (BMP) et reconstruction osseuse des membres,} Sauramps Medical, 2009, 144 pp, broché, 26,00 €, ISBN 978-2-84023-650-4

\author{
Alain Graftiaux
}

Received: 20 December 2010/Accepted: 21 December 2010/Published online: 19 January 2011

(c) Springer-Verlag 2011

The purpose of this book is to have a better knowledge of inductive proteins. It has resulted from the work of the GTEBO (group of study and work on bone morphogenetic protein in orthopaedics).

The first chapter treats osseous consolidation, BMP and osteo-induction in orthopaedics.

The continuation relates to the pseudarthrosis, and the use of the BMP - in general and in more precise-in the humerus, the tibia and the scaphoid.... The book ends with an extension of the BMP to non-osseous tissues and cancers.

This is a book that will make it possible to specify the uses of the BMP. In certain cases of the indications of rescue in other case of the tracks for treatments with a future.

Conflict of interest No funds were received in support of this study. 